\title{
The Metabolism of Homogenates of the Mouse Epididymis
}

\author{
PAUL R. ELLIOTT ${ }^{1}$ \\ Zoology Department, The University of Michigan, Ann Arbor, Michigan
}

\begin{abstract}
This study has attempted an evaluation of the in vitro metabolic characteristics of the epididymis of the mouse and a definition of areas for further research pursuant to the elucidation of the role of this organ in the process of sperm maturation and storage.

Optimal conditions were ascertained for the manometric measurement of total respiration and for the estimation of glycolytic activity by assay of lactate accumulation and phosphate esterification in fluoride poisoned homogenates. Homogenates of mouse kidney were utilized in all experiments for comparative purposes.

The in vitro data presented indicate the epididymis to be predominantly oriented to a glycolytic metabolism. It is suggested that this metabolic orientation when considered with the results of other investigators is compatible with a hypothesis for the secretion of lactic acid by the epididymal epithelium into the lumen of the epididymal canal for spermatozoan utilization.
\end{abstract}

Although it has been established that mammalian spermatozoa undergo changes in their cytology, motility, metabolism and capacity for fertilization during their passage through the epididymis (Mann, '54; Maneely, '59), an inordinately small amount of work has been done on the role of the epididymis in this process. Some investigators (Braus and Redenz, '24) attributed to the epididymis a specific, but unknown, role in this "ripening" process; others (Young, '29a, b) have denied such an active function but all have agreed that in some way the epididymis is adapted for the long term storage of spermatozoa.

Previous investigations of the mammalian epididymis have been predominantly of a descriptive nature. Those investigators who did choose an experimental approach were more concerned with the spermatozoa or the fluids in which these cells reside (cf. Salisbury and Lodge, '62). As a result, knowledge of the functional biochemistry and physiology of this tissue has been inferred rather than direct. A recent exception is the work of Annison et al. ('63) on the in vivo acetate and glucose metabolism of the Ram epididymis.

As a basis for study of the metabolic characteristics of the epididymis, a comparison of the activity of homogenates of this tissue to activity observed in homogenates of kidney from the same animal was undertaken. Results from experiments with kidney could be compared to data in the literature and thus give assurance of reasonable results with the epididymal homogenates.

\section{METHODS}

\section{Animals}

All animals used were penbred, male, BALB/c jax mice, 150-200 days of age, weighing 20-30 gm.

\section{Homogenization}

The experimental animals used were sacrificed by cervical dislocation and the tissues immediately excised, cooled, blotted and weighed. Ten per cent $(w / v)$ homogenates were prepared in isotonic sucrose ( $0.25 \mathrm{M}$ sucrose in $0.025 \mathrm{M}$ phosphate buffer, $\mathrm{pH} 7.4$ ) for measurement of oxidative activity and in alkaline isotonic $\mathrm{KCl}(8.0$ $\mathrm{ml}$ of $0.02 \mathrm{M} \mathrm{KH}_{2} \mathrm{CO}_{3}$ per liter of $0.154 \mathrm{M}$ $\mathrm{KCl}$ ) for the measurement of glycolytic activity.

Ninety seconds of homogenization in an all-glass homogenizer was found to be optimal for the activity of epididymal homogenates. Kidney homogenates were stable at $4^{\circ} \mathrm{C}$ for periods up to four hours. Homogenates of epididymis were quite labile, losing $50 \%$ of their respiratory activity after

Received Sept. 9, '64. Accepted May 6, '65.

1 N.I.H. predoctoral fellow of the National Cancer Institute (CF-9138). Present address: Biology Department, University of Florida, Gainesville, Florida. 
two hours of storage. The addition of $2 \times$ $10^{-5} \mathrm{M}$ nicotinamide held the activity loss to $20 \%$ over that period.

Since no attempt was made in this part of the study to separate the sperm cells from the epididymal tissue, the data presented show the sum of the metabolic rates of these two components. In a separate study (Elliott, '65) using vasa efferentiectomized animals, the sperm contribution was estimated to be $30 \%$ of the oxidative activity and $10-15 \%$ of the glycolytic activity.

\section{Measurement of oxidative activity}

All manometric measurements were made in $9.0 \mathrm{ml}$ single sidearm Warburg flasks containing $1.8 \mathrm{ml}$ of medium and homogenate in the main compartment and $0.2 \mathrm{ml}$ of $10 \% \mathrm{KOH}$ in the center well.

Following a five minute temperature equilibration to $37^{\circ} \mathrm{C}$, the substrates were added from the sidearm and oxygen uptake was measured by the direct method of Warburg (Umbreit et al., '57). Endogenous activity was measured in separate flasks.

The shaking rate of the flasks was two cycles per second with a $2 \mathrm{~cm}$ tranverse. Increased rate of shaking or replacement of the air in the gas space with $95 \% \quad \mathrm{O}_{2-}$ $5 \% \mathrm{CO}_{2}$ resulted in no increase in oxygen uptake.

In all experiments $30 \mathrm{mgm}$ (wet weight) of tissue was used, equivalent to an average of $0.57 \mathrm{mgm}$ (kidney) and $0.36 \mathrm{mgm}$ (epididymis) of tissue nitrogen per flask.

\section{Measurement of anaerobic glycolytic activity}

The flasks were prepared with all constituents except homogenate and placed in an ice-water bath. The homogenate was added and the flasks were flushed with one liter of prepurified nitrogen (Matheson Co., $99.996 \%$ ) per flask while equilibrating to $37^{\circ} \mathrm{C}$. At $0,10,20$, and 40 minutes, duplicate flasks were removed and trichloroacetic acid added to a final concentration of $5 \%$. The contents were centrifuged and the protein free supernatants analyzed for lactic acid and total inorganic phosphate. Lactic acid accumulation is a direct measure of glycolysis in a normally functioning system, and the measurement of net inorganic phosphate change gives an indi- cation of the rate of glycolytic phosphorylation and overall phosphate balance. The measurement of phosphate esterification in glycolyzing homogenates by the method of LePage ('48) requires the inhibition of enolase by fluoride, resulting in the accumulation of esterified phosphate in the form of a stable intermediate, phosphoglyceric acid. In addition, the concentration of fluoride used inhibits ATPase activity. The inhibition of enolase requires that pyruvate be added to the medium as a hydrogen acceptor from the reduced diphosphopyridine nucleotide (DPNH) which is generated at the triose phosphate dehydrogenase step. Fluoride concentrations chosen were a compromise of maximal phosphate esterification and minimal inhibition of glycolysis. The inhibition of enolase by the fluoride concentration used was found to be $85-90 \%$.

\section{Aerobic glycolysis measurements}

The procedure for the measurement of aerobic glycolytic activity (lactate accumulation) of homogenates of epididymis and kidney was identical to that described above with the replacement of nitrogen by $95 \% \mathrm{O}_{2}-5 \% \mathrm{CO}_{2}$, or air.

\section{Quantitative estimations}

Inorganic phosphate was determined by the method of Dwyer et al. ('57); lactic acid by the method of Barker ('57); and total tissue nitrogen by the Levy ('36) Nesslerization method.

\section{Units of activity}

The "Q" notation will be followed except where noted.

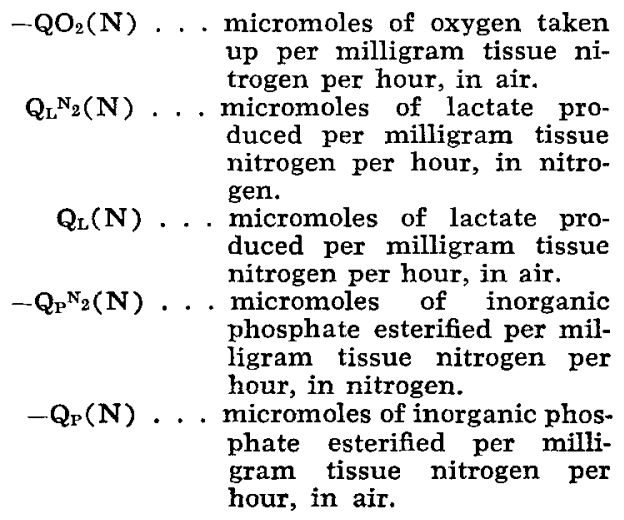


Unless indicated, all data reported are net activity: exogenous minus endogenous. The data reported were obtained from readings taken between the tenth and thirtieth minutes of incubation.

All results were analyzed for statistical differences using standard methods and are reported as the average of duplicate flasks in $\mathrm{N}$ experiments with the corresponding $95 \%$ confidence limits $\left(t_{n} \times S_{\bar{x}}\right.$ where $S_{\bar{x}}$ is standard error of the mean, and $t_{n}$ is the " $t$ " table value for $n$ degrees of freedom).

\section{EXPERIMENTAL RESULTS}

\section{Oxidative activity}

Reaction medium. In order to establish a comparative base for the respiratory activity of the epididymal homogenates, an optimal medium for kidney homogenates (table 1) was adapted from the medium of Krebs ('50). The tonicity, $\mathrm{pH}$, $\mathrm{Mg}^{++}$, and nicotinamide concentrations were adjusted to give maximal oxygen uptake. The metabolizable substrates used were those of the Krebs' medium; glucose, pyruvate, fumarate and glutamate, the concentrations of which were checked to be nonlimiting.

In homogenates of epididymis, the respiratory activity was so low under the conditions imposed that substrate stimulation above endogenous levels was difficult to measure. Of the substrates used only fumarate resulted in a definite stimulation of oxygen uptake. The addition of glucose in the presence of added fumarate resulted in a respiratory rate which was not exceeded by the further addition of glutamate or pyruvate.

Use of this medium, henceforth called the basic medium, resulted in the values of $-\mathrm{QO}_{2}$ for homogenates of epididymis and kidney shown in table 2 along with results of other workers on mouse tissues and on kidney tissue from several animals.

\section{Maximal oxygen uptake in homogenates of epididymis}

The rate of oxygen uptake of homogenates of kidney on the basic medium was not elevated by the addition of adenosine triphosphate (ATP), coenzyme A, thiamine pyrophosphate or triphosphopyridine nucleotide (TPN). The addition of diphosphopyridine nucleotide (DPN) $(2.8 \times$ $\left.10^{-3} \mathrm{M}\right)$ or cytochrome $c\left(1.0 \times 10^{-5} \mathrm{M}\right)$ to respiring kidney homogenates resulted in extension of the period of linear oxygen uptake from 35 to 50 minutes, but no increase in rate was observed. Addition to the basic medium of malate, oxalosucci-

TABLE 1

Basic medium developed for optimal respiratory metabolism of homogenates of mouse kidney. Adapted from Krebs ('50)

\begin{tabular}{|c|c|c|c|}
\hline Additions & & $\underset{\text { molarity }}{\text { Final }}$ & $\begin{array}{c}\mu \text { Moles } \\
\text { added }\end{array}$ \\
\hline $\begin{array}{l}\text { Glucose }{ }^{1} \\
\text { Pyruvate, K salt } \\
\text { Fumarate, K salt } \\
\text { Glutamate, K salt }\end{array}$ & $\begin{array}{l}m l \\
0.1 \\
0.1 \\
0.1 \\
0.1\end{array}$ & $\begin{array}{l}0.01 \\
0.01 \\
0.01 \\
0.01\end{array}$ & $\begin{array}{l}18 \\
18 \\
18 \\
18\end{array}$ \\
\hline $\begin{array}{l}\text { Phosphate buffer }{ }^{2} \\
\text { Magnesium chloride } \\
\text { Nicotinamide } \\
\text { Sucrose }\end{array}$ & $\begin{array}{l}0.9 \\
0.05 \\
0.05 \\
0.1\end{array}$ & $\begin{array}{l}0.025 \\
0.011 \\
0.02 \\
0.05\end{array}$ & $\begin{array}{l}45 \\
20 \\
36 \\
90\end{array}$ \\
\hline $\begin{array}{l}10 \% \text { homogenates in buffered sucrose }(0.25 \mathrm{M}) \\
10 \% \mathrm{KOH} \text { (in well) } \\
\text { Total volume for Warburg studies }\end{array}$ & $\begin{array}{l}0.3 \\
0.2 \\
2.0\end{array}$ & 0.04 & 75 \\
\hline $\begin{array}{l}\mathrm{K} \\
\mathrm{Na}\end{array}$ & & $\begin{array}{l}0.055 \\
0.02\end{array}$ & $\begin{array}{l}98 \\
36\end{array}$ \\
\hline
\end{tabular}

The tonicity of the medium based on a value of 1.0 for isotonic $\mathrm{KCl}$, was 0.98 .

1 Fumarate, glutamate and glucose were obtained from the Nutritional Biochemicals Co.; all other substrates and cofactors were obtained from the Sigma Chemical Co.

2 All additions to the medium were prepared in phosphate buffer, $\left(\mathrm{KH}_{2} \mathrm{PO}_{4}\right.$ and $\mathrm{Na}_{2} \mathrm{HPO}_{4}, 0.25 \mathrm{M}_{4}$ pH 7.4). 
TABLE 2

Oxygen uptake in homogenates of epididymis and kidney compared to data from the literature on related tissues in similar media. All values reported are $\mu$ liters of oxygen taken up/mgm dry weight/hour. Values for epididymis were calculated on the assumption that dry weight was $25 \%$ of wet weight. Values from other papers are from experiments using sliced material. Values given are net uptake of oxygen.

\begin{tabular}{|c|c|c|c|c|c|}
\hline Tissue & Animal & Medium & Substrates & $-\mathrm{QO}_{2}$ & Ref. \\
\hline Kidney, whole & Mouse & Basic med. & $\begin{array}{l}\text { Glucose, pyruv. } \\
\text { glutam., fumar. }\end{array}$ & 33.1 & - \\
\hline Kidney, whole & Mouse & Basic med. & None & 6.9 & - \\
\hline Epididymis & Mouse & Basic med. & As in line 1 & 4.4 & - \\
\hline Epididymis & Mouse & Basic med. & None & 2.7 & - \\
\hline Kidney, whole & Rat & Ringer & Glucose & 23.1 & 1 \\
\hline Kidney, whole & Rat & Ringer & Pyruvate & 26.0 & 1 \\
\hline Kidney, whole & Rat & Ringer & None & 17.8 & 1 \\
\hline Kidney, cortex & Rat & Ca free Ringer & As in line 1 & 36.2 & 2 \\
\hline Kidney, cortex & Mouse & Ca free Ringer & As in line 1 & 46.1 & 2 \\
\hline Kidney, cortex & G. pig & $\mathrm{Ca}$ free Ringer & As in line 1 & 31.8 & 2 \\
\hline Kidney, cortex & Rabbit & Ca free Ringer & As in line 1 & 34.5 & 2 \\
\hline Kidney, cortex & Cat & Ca free Ringer & As in line 1 & 22.7 & 2 \\
\hline Liver & Mouse & Ca free Ringer & As in line 1 & 23.2 & 2 \\
\hline Spleen & Mouse & $\mathrm{Ca}$ free Ringer & As in line 1 & 17.8 & 2 \\
\hline Brain, cortex & Mouse & Ca free Ringer & As in line 1 & 32.9 & 2 \\
\hline Lung & Mouse & Ca free Ringer & As in line 1 & 12.0 & 2 \\
\hline
\end{tabular}

(1) Spector ('56).

(2) Krebs ('50).

nate, or acetate had no effect on the oxygen uptake by the kidney homogenates.

Oxygen uptake by homogenates of epididymis could be considerably elevated by the addition of certain cofactors and substrates which were of interest since they help define the limiting areas of oxidative metabolism of this tissue in vitro.

\section{Cofactors}

No stimulation of oxygen uptake by homogenates of epididymis was observed upon addition of coenzyme $A$, thiamine pyrophosphate or pyridoxal-5-phosphate to the basic medium. However, DPN ( $5.5 \times$ $10^{-4} \mathrm{M}$ ) addition stimulated the respiratory activity even in the presence of added nicotinamide (table 3 ). In the absence of nicotinamide, DPN additions $(2.8 \times$ $10^{-3} \mathrm{M}$ ) resulted in a $50 \%$ stimulation. Cytochrome $c$ addition $\left(1.0 \times 10^{-5} \mathrm{M}\right)$ elevated oxygen uptake slightly when added to the basic medium, but resulted in no change of rate in the presence of added DPN. ATP $\left(4.4 \times 10^{-3} \mathrm{M}\right)$ added to the basic medium gave results similar to those observed with cytochrome $c$.

\section{Substrates}

Citrate, isocitrate, oxalosuccinate and malate added (18 $\mu$ moles) as single substrates to the basic medium (containing pyruvate, glucose, fumarate and glutamate) failed to effect the rate of oxygen uptake by homogenates of epididymis. Citrate and isocitrate added singly to the basic medium devoid of fumarate and glutamate (table 4) resulted in no stimulation of net oxygen uptake even in the presence of added DPN or TPN $\left(5.5 \times 10^{-4} \mathrm{M}\right)$. The addition of malate or succinate under these conditions gave rates equivalent to the respective basic medium incubation. The implication of these results is the occurrence of a block in the tricarboxylic acid cycle in the area of citrate to a-ketoglutarate. It should be emphasized that even with added ATP, DPN, cytochorme $c$ and succinate the rate of oxygen uptake of homogenates of epididymis is only onefifth that of the kidney homogenates. 
TABLE 3

Effect of cofactor additions to the basic medium on oxygen uptake by homogenates of epididymis. Additions were DPN $\left(5.5 \times 10^{-4} M\right), A T P\left(4.4 \times 10^{-3} \mathrm{M}\right)$ and cytochrome $c\left(1 \times 1^{-5} M\right)$

\begin{tabular}{|c|c|c|c|c|}
\hline \multirow{2}{*}{$\begin{array}{l}\text { Additions } \\
\text { to the } \\
\text { medium }\end{array}$} & \multirow{2}{*}{$\begin{array}{c}\text { Nicotinamide } \\
(0.66 \mathrm{M})\end{array}$} & \multirow{2}{*}{$-\mathrm{QO}_{2}(\mathrm{~N})$ Epid. } & \multicolumn{2}{|c|}{$\%$ Increase over } \\
\hline & & & (A) & (B) \\
\hline $\begin{array}{l}\text { None } \\
\text { None }\end{array}$ & $\begin{array}{l}+(A) \\
-(B)\end{array}$ & $\begin{array}{l}4.1 \pm 0.3(20) \\
2.6 \pm 0.8(9)\end{array}$ & 0 & 58 \\
\hline $\begin{array}{l}\text { DPN } \\
\text { DPN }\end{array}$ & + & $\begin{array}{l}5.2 \pm 1.2 \\
3.9 \pm 1.8\end{array}$ & 27 & $\overline{50}$ \\
\hline $\begin{array}{l}\text { ATP } \\
\text { ATP }\end{array}$ & + & $\begin{array}{l}4.5 \pm 1.2(4) \\
3.7 \pm 1.6\end{array}$ & 10 & $\overline{42}$ \\
\hline $\begin{array}{l}\text { Cyt. c } \\
\text { Cyt. c }\end{array}$ & + & $\begin{array}{l}4.7 \pm 0.8(5) \\
3.1 \pm 0.7\end{array}$ & 15 & $\overline{19}$ \\
\hline $\begin{array}{l}\text { DPN, Cyt. c } \\
\text { DPN, Cyt. c }\end{array}$ & \pm & $\begin{array}{l}5.0 \pm 1.3 \\
5.1 \pm 2.3(2)\end{array}$ & 22 & $\overline{96}$ \\
\hline $\begin{array}{l}\text { DPN, ATP } \\
\text { DPN, ATP }\end{array}$ & \pm & $\begin{array}{l}5.0 \pm 1.9 \\
4.7 \pm 1.2\end{array}$ & 22 & $\overline{80}$ \\
\hline $\begin{array}{l}\text { DPN, ATP, Cyt. c } \\
\text { DPN, ATP, Cyt. c }\end{array}$ & \pm & $\begin{array}{l}5.5 \pm 1.0(8) \\
5.1 \pm 1.6(5)\end{array}$ & $\underline{34}$ & $\overrightarrow{96}$ \\
\hline
\end{tabular}

Values reported above are averages of duplicate flasks in $\mathrm{N}$ experiments followed by the $95 \%$ confidence limits. $\mathrm{N}=3$ for all data unless otherwise indicated in parentheses.

TABLE 4

The effects of varied substrate additions on oxygen uptake by homogenates of epididymis. ATP $\left(4.4 \times 10^{-3} \mathrm{M}\right)$, DPN $\left(5.5 \times 10^{-4} \mathrm{M}\right), \mathrm{TPN}\left(5.5 \times 10^{-4} \mathrm{M}\right)$ and all substrates $(0.01 \mathrm{M})$ were added to the basic kidney medium in the presence or absence of fumarate and glutamate.

\begin{tabular}{|c|c|c|c|c|}
\hline $\begin{array}{l}\text { Substrate } \\
\text { additions }\end{array}$ & $\begin{array}{l}\text { Cofactor } \\
\text { additions }\end{array}$ & $\begin{array}{c}\text { Glutamate, } \\
\text { fumarate }\end{array}$ & $\begin{array}{l}-\mathrm{QO}_{2}(\mathrm{~N}) \\
\text { epididymis }\end{array}$ & $\mathbf{N}$ \\
\hline $\begin{array}{l}\text { None }{ }^{1} \\
\text { None }\end{array}$ & $\begin{array}{l}\text { none } \\
\text { none }\end{array}$ & \pm & $\begin{array}{l}4.1 \pm 0.3 \\
0.8 \pm 0.08\end{array}$ & $\begin{array}{r}20 \\
5\end{array}$ \\
\hline $\begin{array}{l}\text { Isocitrate } \\
\text { Isocitrate }\end{array}$ & $\begin{array}{l}\text { none } \\
\text { none }\end{array}$ & + & $\begin{array}{l}4.0 \pm 1.3 \\
1.2 \pm 0.4\end{array}$ & $\begin{array}{l}3 \\
3\end{array}$ \\
\hline $\begin{array}{l}\text { Citrate } \\
\text { Citrate }\end{array}$ & $\begin{array}{l}\text { none } \\
\text { none }\end{array}$ & \pm & $\begin{array}{l}4.2 \pm 0.4 \\
0.2 \pm 0.1\end{array}$ & $\begin{array}{l}2 \\
2\end{array}$ \\
\hline $\begin{array}{l}\text { Malate } \\
\text { Malate }\end{array}$ & $\begin{array}{l}\text { none } \\
\text { none }\end{array}$ & + & $\begin{array}{l}3.8 \pm 0.8 \\
3.8 \pm 0.4\end{array}$ & $\begin{array}{l}2 \\
3\end{array}$ \\
\hline Oxalosuccinate & none & + & $3.9 \pm 0.9$ & 4 \\
\hline Succinate & none & - & $3.6 \pm 1.3$ & 3 \\
\hline $\begin{array}{l}\text { Isocitrate } \\
\text { Succinate } \\
\text { Succ. and Isocit. }\end{array}$ & $\begin{array}{l}\text { DPN, TPN } \\
\text { DPN, TPN } \\
\text { DPN, TPN }\end{array}$ & $\overline{-}$ & $\begin{array}{l}1.4 \pm 0.3 \\
5.6 \pm 1.6 \\
5.8 \pm 1.2\end{array}$ & $\begin{array}{l}4 \\
5 \\
5\end{array}$ \\
\hline $\begin{array}{l}\text { Succinate } \\
\text { None }\end{array}$ & $\begin{array}{l}\text { DPN, TPN, } \\
\text { ATP, Cyt. c } \\
\text { DPN, TPN, } \\
\text { ATP, Cyt. c }\end{array}$ & $\begin{array}{l}+ \\
+\end{array}$ & $\begin{array}{l}5.9 \pm 0.4 \\
5.5 \pm 0.3\end{array}$ & 6 \\
\hline
\end{tabular}

Values reported above are averages of duplicate flasks in $N$ experiments followed by the $95 \%$ confidence limits. Values for $N$ are shown in the last column.

1 Glucose and pyruvate as per the basic medium were added throughout this set of experiments. 
High energy phosphate balance
in homogenates

An indication of the balance between phosphorylative and dephosphorylative systems can be obtained by the manipulation, in vitro, of the phosphate acceptors (adenosine diphosphate [ADP], and inorganic phosphate), uncoupling agents (dinitrophenol [DNP]) and inhibitors of dephosphorylating processes (fluoride).

The resopnse of kidney homogenates to DNP (EKco no. 102) uncoupling, fluoride poisoning and addition of ADP was as expected from the reported mechanisms of these compounds in an actively respiring homogenate with intact mitochondria. The addition of DNP $\left(2.8 \times 10^{-5} \mathrm{M}\right)$ stimulated oxygen uptake $25 \%$ in the presence of and $68 \%$ in the absence of optimal inorganic phosphate $(0.025 \mathrm{M})$. The addition of ADP $(0.004 \mathrm{M})$ in the presence of inorganic phosphate stimulated oxygen uptake in the kidney homogenate, and fluoride poisoning $(0.02 \mathrm{M})$ inhibited oxygen uptake $25-30 \%$ under the same conditions.

No stimulation of oxygen uptake in homogenates of epididymis was observed with varied inorganic phosphate, ADP or DPN (table 5). The addition of fluoride

\section{TABLE 5}

Experiments on phosphorylative balance in homogenates of epididymis. The assay system was that found to be optimal for respiring homogenates of epididymis (basic kidney medium with added DPN, ATP, Cyt. c and succinate). Additions to the assay system were dinitrophenol (DNP) $\left(2.8 \times 10^{-5} \mathrm{M}\right), A D P(0.004 \mathrm{M})$ and fluoride $(0.02 \mathrm{M})$. Total volume in flasks: $1.8 \mathrm{ml}$.

\begin{tabular}{lll}
\hline $\begin{array}{c}\text { Added } \\
\text { phosphate }\end{array}$ & $\begin{array}{c}\text { Additions to } \\
\text { optimal med. }\end{array}$ & \multicolumn{1}{c}{$\begin{array}{c}-\mathrm{QO}_{2}(\mathrm{~N}) \\
\text { Epididymis }\end{array}$} \\
\hline $0.025 \mathrm{M}$ & None & $5.5 \pm 1.0(20)$ \\
0 & None & $5.0 \pm 1.3(4)$ \\
$0.025 \mathrm{M}$ & DNP & $4.9 \pm 0.7(4)$ \\
0 & DNP & $4.7 \pm 2.1(2)$ \\
$0.025 \mathrm{M}$ & ADP & $5.7 \pm 0.8$ \\
0 & ADP & $5.2 \pm 1.3$ \\
$0.025 \mathrm{M}$ & Fluoride & $5.0 \pm 1.6(4)$ \\
0 & Fluoride & $4.9 \pm 1.8(2)$ \\
$0.025 \mathrm{M}$ & None 1 & $4.1 \pm 0.3(20)$ \\
$0.025 \mathrm{M}$ & Fluoride & $5.3 \pm 1.2(5)$ \\
\hline
\end{tabular}

Values reported above are averages of duplicate flasks in $N$ experiments followed by the $95 \%$ confidence limits. $N=3$ for all data unless otherwise indicated in parentheses.

1 The basic medium (optimal medium for epididymis without DPN, ATP, cytochrome $c$ and succinate) was used for these experiments.
$(0.02 \mathrm{M})$ to the respiring epididymal homogenates resulted in an increased rate of oxygen uptake in the basic medium. The effect of fluoride is similar to that observed when ATP is added to the basic medium and is suggestive of a low level of ATP formation in vitro, or a high ATPase activity. Coupled with the observation that DPN addition to the medium is required for maximal in vitro oxidative activity, these results indicate a definite imbalance in oxidative phosphorylative processes.

\section{Anaerobic glycolysis in homogenates of epididymis and kidney}

Development of optimal media. Glycolytic rates in optimal media have been reported for tumor tissues (LePage, '48) and rat liver homogenates (Stoesz and LePage, '49), and have been applied to a number of normal tissue homogenates from rats, rabbits and mice (LePage, '50). For this study, the constituents of the medium for rat liver homogenates were varied singly to obtain optima for tonicity, $\mathrm{pH}$, and concentrations of added ATP, fructose1-6-diphosphate (HDP), inorganic phosphate and glucose. In cases where the optimal concentration for lactate production and phosphate esterification were different, the final concentration was a compromise. The optimal reaction media are shown in table 6.

In table 7 are shown the values obtained in this study for lactate accumulation and phosphate esterification in homogenates of epididymis and kidney, as well as for various mammalian tissues on media similar to those used in this study. The value of $\mathrm{Q}_{\mathrm{L}}{ }^{\mathrm{N}_{2}}(\mathrm{~N})$ for homogenates of epididymis was $35.3 \pm 1.4 \quad(N=12)$; for homogenates of kidney, $38.1 \pm 2.5(\mathrm{~N}=10)$. The respective $-\mathrm{Q}_{\mathrm{P}} \mathrm{N}_{2}(\mathrm{~N})$ values were $5.4 \pm 1.3$ $(\mathrm{N}=12)$ for homogenates of epididymis and $-10.1 \pm 2.7(\mathrm{~N}=10)$ for kidney. Of particular significance is the net esterification of inorganic phosphate by homogenates of epididymis. In the presence of high fluoride concentrations $(0.04 \mathrm{M})$, the ratio of micromoles of phosphate esterified to micromoles of lactate produced approached 0.7 in this tissue. The production of lactate was inhibited $35 \%$ under these conditions. A net uptake of inorganic phosphorous was never observed in 
TABLE 6

Optimal media developed for the measurement of glycolytic activity in homogenates of epididymis and kidney; adapted from the work of Stoesz and LePage ('49)

\begin{tabular}{|c|c|c|c|}
\hline \multirow{2}{*}{ Additions } & & \multicolumn{2}{|c|}{ Final molarity } \\
\hline & & Epididymis & Kidney \\
\hline & $m l$ & & \\
\hline Deionized water & 0.7 & $\ldots$ & - \\
\hline Phosphate buffer ${ }^{1}$ & 0.3 & 0.0024 & 0.0024 \\
\hline Potassium bicarbonate & 0.15 & 0.05 & 0.05 \\
\hline Potassium fluoride & 0.15 & 0.01 & 0.01 \\
\hline Magnesium chloride & 0.2 & 0.0066 & 0.0066 \\
\hline Nicotinamide & 0.3 & 0.04 & 0.03 \\
\hline DPN & 0.2 & $3.3 \times 10^{-4}$ & $1.7 \times 10^{-4}$ \\
\hline ATP ${ }^{2}$ & 0.1 & $8.0 \times 10^{-4}$ & $1.3 \times 10^{-3}$ \\
\hline HDP & 0.15 & 0.0033 & 0.0066 \\
\hline Glucose & 0.3 & 0.0033 & water \\
\hline Pyruvate & 0.15 & 0.0066 & 0.01 \\
\hline $10 \%$ Homogenate in isotonic, buffered $\mathrm{KCl}$ & 0.3 & 0.015 & 0.015 \\
\hline Total volume & 3.0 & \multicolumn{2}{|c|}{ final pH 7.4} \\
\hline
\end{tabular}

1 Made up of $0.024 \mathrm{M} \mathrm{KH}_{2} \mathrm{PO}_{4}$ and $\mathrm{K}_{2} \mathrm{HPO}_{4}$, $\mathrm{pH} 7.4$.

2 ATP, DPN, HDP and pyruvate were added as their potassium salts.

TABLE 7

Reported values for lactate accumulation and phosphate esterification in anaerobically glycolyzing homogenates of various tissues. All values have been converted to micromoles per 40 minute incubation per $30 \mathrm{mgm}$ (wet weight) of homogenized tissue.

\begin{tabular}{|c|c|c|c|c|}
\hline Tissue & Animal & $\begin{array}{l}\text { Micromoles } \\
\text { lactate } \\
\text { accumulated }\end{array}$ & $\begin{array}{l}\text { Micromoles } \\
\text { phosphate } \\
\text { esterified }\end{array}$ & Ref. \\
\hline Epididymis & mouse & $8.3 \pm 1.0$ & $1.3 \pm 0.5$ & - \\
\hline Kidney & mouse & $13.2 \pm 1.9$ & $-3.8 \pm 0.8$ & - \\
\hline Kidney & rat & 6.8 & -2.3 & 11 \\
\hline Kidney & rabbit & 5.8 & -3.1 & 1 \\
\hline Kidney & mouse & 4.1 & 0 & 1 \\
\hline Liver & rat & 6.8 & -1.4 & 1 \\
\hline Liver & mouse & 4.1 & -0.77 & 1 \\
\hline Liver & rabbit & 5.5 & -0.25 & 1 \\
\hline Liver & rat & 14.0 & -4.0 & 2 \\
\hline F. J. tumor & rat & 9.5 & 4.5 & 3 \\
\hline Brain & rat & 9.8 & 6.5 & 1 \\
\hline Heart & rat & 9.9 & -0.4 & 1 \\
\hline Sk. muscle & rat & 8.7 & -5.3 & 1 \\
\hline
\end{tabular}

1 Values reported from reference 1 are not necessarily maximal; the medium used was optimal for Flexner-Jobling tumor.

References: (1) LePage ('50); (2) Stoesz and LePage ('49); (3) LePage ('48).

homogenates of kidney even in the presence of high fluoride concentrations.

\section{DPN and nicotinamide}

The effect of varied DPN concentration on lactate accumulation and phosphate esterification in homogenates of epididymis and kidney confirmed the results obtained in the previous section on oxidative metabolism. The addition of DPN ( $1.0 \times$ $10^{-4} \mathrm{M}$ ) to homogenates of kidney in the presence of optimal nicotinamide had a slight stimulating effect on the rate of lac- tate accumulation. Under the same conditions, homogenates of epididymis were observed to require DPN $\left(3.3 \times 10^{-4} \mathrm{M}\right)$ for optimal glycolytic activity. Figure 1 shows the effect of added DPN in the presence and absence of optimal nicotinamide. Apparently, under the in vitro conditions imposed, the homogenates have an active DPNase as well as a lack of available DPN.

\section{Substrates supporting glycolysis}

The results of experiments with glycolyzable substrates indicated that fructose 


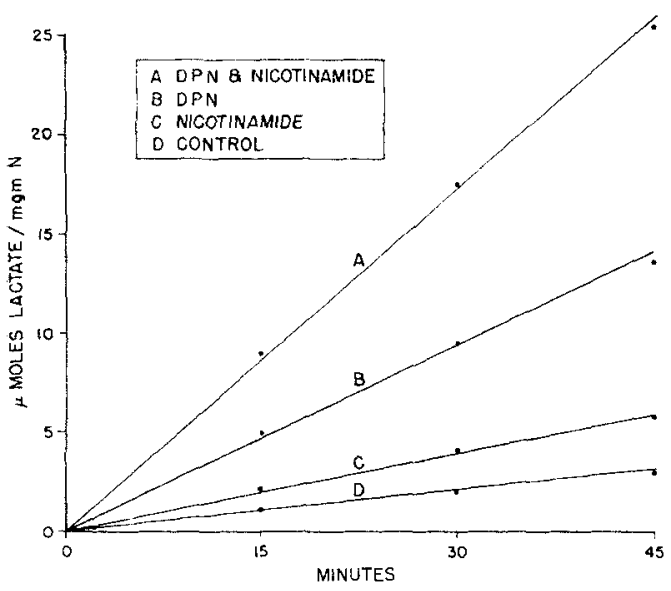

Fig. 1 The effect of added DPN $\left(3.3 \times 10^{-4} \mathrm{M}\right)$ and nicotinamide $(0.04 \mathrm{M})$ on the accumulation of lactate by homogenates of epididymis. The media were otherwise optimal. Data are the average of three experiments for each curve.

and glucose were equivalent for these homogenates, and that fructose-6-phosphate or glucose-6-phosphate as single substrates could support glycolysis (in kidney, $20 \%$ and in epididymis, $45 \%$ of the maximal rate with HDP and glucose as substrates). In homogenates of epididymis, in the presence of low levels of HDP, glucose was as efficient as glucose-6-phosphate in support of anaerobic glycolysis. This was not true for kidney homogenates, and may account for the net esterification of phosphate observed in the epididymal homogenates on optimal media, since it must result from the ability of this tissue to phosphorylate glucose in vitro.
A further indication of this phosphorylative activity is the higher requirement of ATP by homogenates of kidney (table 8 ), an effect similar to that reported by Stoesz and LePage ('49) in homogenates of liver. They attribute this requirement to the $a b$ sence of glucose phosphorylation resulting in a lack of available ADP, a cofactor required for the conversion of 1-3-diphosphoglyceric acid to 3-phosphoglyceric acid. This interpretation was substantiated in experiments where ADP was added to the medium in place of and in addition to ATP (table 8). ADP could substitute for ATP in homogenates of kidney which is apparently relying on ATPase to supply the necessary phosphate acceptors, but not in homogenates of epididymis in this medium, where glucose phosphorylation is necessary for the maximal rate of glycolysis. The requirement of glucose phosphorylation can be relieved for homogenates of epididymis by doubling the HDP concentration; ADP can then substitute for ATP as was noted for kidney homogenates. Table 9 indicates that the rate of lactate accumulation in kidney homogenates is independent of glucose concentration. The epididymal homogenates, however, can glycolyze glucose anaerobically, and in the presence of catalytic amounts of HDP ( $1 \mu$ mole), the net lactate accumulation exceeds that expected from the added HDP alone. It is further indicated that this glucolysis is ATP dependent. LePage ('48) and Stoesz and LePage ('49) reported that homogenates of most normal, adult, mammalian tissues are in-

TABLE 8

The response of homogenates of epididymis and kidney to varied ATP and ADP in otherwise optimal media, as measured by lactate production and phosphate esterification

\begin{tabular}{|c|c|c|c|c|c|}
\hline \multicolumn{2}{|c|}{$\mu \mathrm{M}$ Added } & \multicolumn{2}{|c|}{ Kidney } & \multicolumn{2}{|c|}{ Epididymis } \\
\hline ATP & ADP & $Q_{L}^{N_{2}}(N)$ & $-Q_{P_{2}}^{N_{2}}(N)$ & $\mathbf{Q}_{\mathrm{L}}^{N_{2}}(\mathrm{~N})$ & $-Q_{\mathbf{P}}^{N_{2}}(N)$ \\
\hline $\begin{array}{l}0 \\
1.0 \\
2.5 \\
5.0 \\
3.0 \\
0 \\
0\end{array}$ & $\begin{array}{l}0 \\
0 \\
0 \\
0 \\
3.0 \\
3.0 \\
5.0\end{array}$ & $\begin{array}{r}6.2 \pm 1.3 \\
18.7 \pm 2.9 \\
29.2 \pm 1.4 \\
38.7 \pm 3.9 \\
39.3 \pm 3.0 \\
31.6 \pm 2.8 \\
38.3 \pm 3.1\end{array}$ & $\begin{array}{r}-13.6 \pm 2.6 \\
-13.4 \pm 2.7 \\
-12.3 \pm 1.0 \\
-11.2 \pm 9.1 \\
-9.8 \pm 2.3 \\
-8.7 \pm 1.2 \\
-10.2 \pm 1.6\end{array}$ & $\begin{array}{r}8.4 \pm 0.9 \\
34.0 \pm 2.9 \\
34.7 \pm 3.0 \\
32.6 \pm 2.9 \\
33.8 \pm 3.2 \\
26.7 \pm 3.1 \\
28.7 \pm 2.9\end{array}$ & $\begin{array}{r}-2.1 \pm 0.6 \\
3.6 \pm 0.9 \\
5.6 \pm 1.2 \\
4.0 \pm 1.9 \\
5.2 \pm 1.4 \\
3.8 \pm 1.1 \\
3.6 \pm 2.1\end{array}$ \\
\hline \multicolumn{3}{|c|}{ Optimal ATP additions selected: } & $\begin{array}{l}\text { idymis, } 4.0 \mu \text { Moles } \\
\text { idyoles }\end{array}$ & & \\
\hline
\end{tabular}

Values reported above are averages of duplicate flasks in $\mathbf{N}$ experiments followed by the $95 \%$ confidence limits. $\mathrm{N}=3$ for all data. 
capable of glucose phosphorylation under anaerobic, in vitro conditions. Brain tissue, heart muscle and certain tumors are exceptions.

The observations to this point indicated an efficient anaerobic metabolism for homogenates of epididymis, particularly with regard to the phosphorylative balance, and at best an inefficient oxidative metabolism. It was felt these results might be extended by measurement of the Pasteur effect in these homogenates.

\section{Aerobic glycolysis in homogenates of epididymis and kidney}

Under certain conditions, aerobic glycolysis as compared to the anaerobic activity is characterized by a lowered rate of glucose utilization and lactate accumulation, possibly due to the removal of inorganic phosphate from the cell as an acceptor for oxidative phosphorylation without the return of ATP for glucose phosphorylation. In addition, the removal of inorganic phosphate inhibits the triose phosphate dehydrogenase reaction, reducing the rate of glycolysis, and further lowering the available glycolytically formed ATP (Chance and Hess, '59; Racker and $W u$, '59 and Lynen et al., '59). This phenomenon, designated the Pasteur effect after its discoverer, can thus indicate the relative efficiencies of the respective oxidative and glycolytic portions of a system. It was for this reason that measurements of aerobic glycolysis were made on these homogenates.

Comparing the aerobic to the anaerobic rates, it is apparent (table 10) that the presence of oxygen or the removal of fluoride or inorganic phosphate from the medium resulted in a reduction of the rate of accumulation of lactate in homogenates of kidney, as did the addition of succinate in the absence of fluoride. The addition of DNP $\left(2.8 \times 10^{-5} \mathrm{M}\right)$ relieved this inhibition.

In no instance was the rate of aerobic lactate accumulation in homogenates of epididymis observed to be lower than the anaerobic rate, as might have been predicted from the low oxidative capacity of this tissue previously observed.

\section{DISCUSSION}

The data presented in this study of the epididymis of the mouse are indicative of a tissue which is oriented predominantly to a glycolytic metabolism. Of particular interest was the low oxidative capacity of homogenates of this tissue $\left(-\mathrm{QO}_{2}==4-5\right)$ even in the presence of added ATP, DPN and cytochrome $c$. The limiting factors for this low respiratory activity were not established, but the results indicated the following to be of significance: (1) the high

TABLE 9

Relationship of HDP and glucose concentrations to maximal lactate accumulations by homogenates of epididymis and kidney. Glucose stimulation of glycolytic activity above levels observed with optimal HDP as substrate is also shown. Media were optimal in all other respects.

\begin{tabular}{|c|c|c|c|c|}
\hline \multicolumn{2}{|c|}{ Additions in micromoles } & \multicolumn{3}{|c|}{$\begin{array}{l}\text { Net micromoles of lactate accumulated } \\
\text { by } 30 \mathrm{mgm} \text { of tissue in a } 60 \mathrm{minute} \text { incubation }\end{array}$} \\
\hline Glucose & HDP & Kidney & Epididymi & \\
\hline $\begin{array}{l}10^{1} \\
10 \\
10 \\
10 \\
0\end{array}$ & $\begin{array}{l}0^{2} \\
10^{2} \\
20^{3} \\
30^{3} \\
20^{2}\end{array}$ & $\begin{array}{l}0 \\
13.5 \pm 1.6 \quad(4) \\
22.0 \pm 2.3 \quad(5) \\
22.6 \pm 2.6 \\
21.1 \pm 3.2\end{array}$ & $\begin{array}{r}0.8 \pm 0.2 \\
12.6 \pm 1.8 \\
11.2 \pm 2.9 \\
12.9 \pm 1.6 \\
8.1 \pm 1.3\end{array}$ & $\begin{array}{l}(2) \\
(4) \\
(2) \\
(2)\end{array}$ \\
\hline $\begin{array}{l}0 \\
0 \\
5 \\
5 \\
5\end{array}$ & $\begin{array}{l}0 \\
1 \\
1 \\
1^{4} \\
0\end{array}$ & $\begin{array}{l}0 \\
1.6 \pm 0.2 \\
1.8 \pm 0.15(5) \\
1.2 \pm 0.3 \\
0\end{array}$ & $\begin{array}{l}0 \\
1.4 \pm 0.3 \\
3.3 \pm 1.0 \\
1.9 \pm 0.6 \\
0.2 \pm 0.04\end{array}$ & $\begin{array}{l}(7) \\
(4)\end{array}$ \\
\hline
\end{tabular}

Values reported above are averages of duplicate flasks in $\mathbf{N}$ experiments followed by the $95 \%$ confidence limits. $\mathrm{N}=3$ for all data unless otherwise indicated in parentheses.

1 Optimal glucose concentration for epididymal medium.

2 Optimal HDP addition for epididymal medium.

3 Optimal HDP addition for epididymal med

4 ATP deleted from the media as a control. 
TABLE 10

Lactic acid accumulation by homogenates of epididymis and kidney under aerobic conditions (air) and anaerobic conditions (nitrogen). The media were those found to be optimal for anaerobic glycolysis. Deviations from the standard media are indicated in column 1 . DNP was added to $2.8 \times$ $10^{-5} \mathrm{M}$ and succinate was added to $0.006 \mathrm{M}$.

\begin{tabular}{|c|c|c|c|c|c|c|}
\hline \multirow{2}{*}{$\begin{array}{l}\text { Changes in the } \\
\text { optimal media }\end{array}$} & \multicolumn{3}{|c|}{ Kidney } & \multicolumn{3}{|c|}{ Epididymis } \\
\hline & $Q_{L}^{N_{2}}(N)$ & $Q_{L}(N)$ & $\begin{array}{l}\% \\
\text { Loss }\end{array}$ & $Q_{\mathrm{L}}^{N_{2}}(\mathrm{~N})$ & $Q_{L}(N)$ & $\begin{array}{c}\% \\
\text { Loss }\end{array}$ \\
\hline None & $36.5 \pm 4.1$ & $31.6 \pm 3.2$ & 11 & $35.3 \pm 3.0$ & $36.2 \pm 2.7$ & 0 \\
\hline None $\left(\begin{array}{lll}95 \% & \mathrm{O}_{2}\end{array}\right)$ & $37.5 \pm 4.8$ & $29.6 \pm 3.3$ & 16 & $33.4 \pm 4.0$ & $33.9 \pm 3.9$ & 0 \\
\hline - Fluoride & $37.9 \pm 5.0$ & $28.3 \pm 4.2$ & 26 & $35.3 \pm 2.9$ & $33.9 \pm 3.7$ & 0 \\
\hline - Fluor., pyruvate & $32.6 \pm 2.7$ & $25.2 \pm 2.9$ & 23 & $30.2 \pm 1.7$ & $31.3 \pm 1.6$ & 0 \\
\hline $\begin{array}{l}\text {-Fluor., pyruvate } \\
\text { and phosphate }\end{array}$ & $14.3 \pm 3.9$ & $11.1 \pm 1.5$ & 22 & $17.2 \pm 1.6$ & $15.3 \pm 1.4$ & 11 \\
\hline -Fluor., phosphate & $17.0 \pm 2.1$ & $11.2 \pm 3.1$ & 34 & $19.3 \pm 2.3$ & $16.9 \pm 1.3$ & 12 \\
\hline - Phosphate & $18.2 \pm 1.9$ & $17.3 \pm 2.6$ & 5 & $21.3 \pm 2.7$ & $21.4 \pm 3.9$ & 0 \\
\hline + Succinate & $35.2 \pm 4.6$ & $31.1 \pm 3.2$ & 12 & $34.8 \pm 2.6$ & $32.7 \pm 2.1$ & 7 \\
\hline + Succinate, - fluor. & $31.7 \pm 3.8$ & $24.3 \pm 4.1$ & 23 & $29.6 \pm 2.9$ & $26.3 \pm 3.1$ & 11 \\
\hline+ DNP & $36.2 \pm 4.7$ & $38.1 \pm 3.2$ & 0 & $33.3 \pm 3.9$ & $32.9 \pm 4.5$ & 0 \\
\hline + DNP, - fluoride & $38.2 \pm 3.7$ & $37.3 \pm 4.0$ & 0 & $36.1 \pm 2.8$ & $34.9 \pm 5.6$ & 0 \\
\hline $\begin{array}{l}+ \text { Succinate, }- \text { fluor., } \\
\text { - phosphate }\left(95 \% \mathrm{O}_{2}\right)\end{array}$ & $19.3 \pm 2.7$ & $12.4 \pm 1.4$ & 36 & $20.7 \pm 3.0$ & $18.9 \pm 2.6$ & 9 \\
\hline
\end{tabular}

Values reported above are averages of duplicate flasks in $N$ experiments followed by the $95 \%$ confidence limits. $\mathrm{N}=\mathbf{5}$ for all data reported.

in vitro level of diphosphopyridine nucleotide nucelosidase as measured indirectly with additions of DPN and nicotinamide, and evidence of low levels of DPN in this tissue, and (2) the low aerobic phosphorylation level focused attention on the terminal oxidases and their coupled phosphorylative activity as an area deserving of more attention. In addition, (3) an apparent block in tricarboxylic acid cycle activity was observed, occurring between citrate and a-ketoglutarate. This block could not properly be accounted for by low activity of the terminal oxidases since oxygen uptake on the substrates fumarate, malate or succinate was 3-4 times greater than that observed with isocitrate.

The possibility still exists that proper treatment of the homogenates of epididymis was not encountered. This, however, seems unlikely since (1) intact mitochondria were observed in these homogenates by microscopic examination, (2) slices and minces gave similar results for oxygen uptake, and (3) twenty variants in homogenization media were tried for this tissue with no increased rate of respiration observed. Further, the validity of these measurements of respiratory activity was enhanced by the simultaneous and identical treatment of homogenates of kidney and epididymis from the same mouse and comparison of the results with kidney tissue to results in the literature.

The rates of anaerobic glycolysis in homogenates of epididymis and kidney, as measured in a fluoride blocked system, were equivalent; a result which was not surprising since LePage ('48, '50) and Stoesz and LePage ('49) obtained comparable rates of glycolytic activity in a number of normal and tumor tissues from different animals when the substrate was glycolyzable.

Homogenates of epididymis and kidney differed significantly in their capacity for anaerobic glucolysis, this capacity being present only in homogenates of epididymis. This ability to phosphorylate glucose anaerobically places the epididymis in a select group of tissues including brain, cortex, and most tumors, as well as normal tissues from newborn animals. No correlation between this capacity for glucolysis and any other attribute of these tissues is apparent. LePage ('50) suggested that the glucolytic capacity of tissues of newborn animals was related to the lack of adrenal cortical activity at that time. 
The glucolytic activity observed in homogenates of epididymis resulted in an efficient anaerobic glycolytic phosphate balance (net esterification) in contrast to the preponderance of dephosphorylative activity observed under aerobic conditions with oxidizable substrates.

The high aerobic glycolytic rate of homogenates of epididymis is most likely a reflection of the failure of oxidative processes to compete for the common cofactors (ADP, DPNH, inorganic phosphate). The accumulation of lactate in homogenates of kidney was considerably lowered under aerobic conditions and further inhibited under conditions which favored an increased rate of oxidative phosphorylation (e.g. added succinate) or removal of inorganic phosphate from the medium.

The total evidence for the predominantly glycolytic metabolism of the epididymis in vitro is of interest in light of published data concerning the metabolism of epididymal sperm (cf. Salisbury and Lodge, '62). The general emphasis of these reports is the efficient maintenance of epididymal sperm by oxidative processes as compared to the glycolytic character of ejaculate sperm. Henle and Zittle ('42) demonstrated a large Pasteur effect in bovine epididymal sperm, but in ejaculate sperm from most animals the aerobic and anaerobic glycolytic rates were equivalent. Lardy et al. ("45) reported that of those substrates supporting oxidative metabolism in bovine epididymal spermatozoa, pyruvate and lactate were 3-5 times more efficient than glucose, acetate, or the diand tricarboxylic acids.

An interesting aspect of sperm metabolism (Terner, '62) involves an active pyruvate dismutation reaction in bull spermatozoa where two molecules of pyruvate react with $\mathrm{CoA}$ to form lactate, $\mathrm{CO}_{2}$ and acetyl-CoA even in the presence of active glycolysis. He further showed that this acetyl-CoA was utilized to a significant extent for the biosynthesis of fatty acids. Hartree and Mann ('58, '59, '60) have published convincing data that the major endogenous substrate for sperm maintenance is lipid (plasmalogen) in nature.

Flipse ('62) has demonstrated an active pyruvate linked transaminase system in bovine spermatozoa and has presented fur- ther evidence for the presence of significant protein biosynthesis in these sperm cells.

Thus, although the metabolism of epididymal sperm is not completely delineated, a significant number of oxidative, anaerobic, synthetic and degradative pathways have been shown to involve or be limited by the level of pyruvate. It would appear that the glycolytic nature of epididymal epithelium in the mouse, if it holds true in vivo would be an efficient means of furnishing lactate or some other glycolytic end product for sperm utilization. The report of Mann and Glover ('54) showing relatively high $(20 \mathrm{mgm} / 100 \mathrm{ml})$ concentrations of lactate in Boar epididymal secretions and in the ejaculate semen of Boar, Man, Bull and Ram would support this hypothesis. Further support is found in a report of Allen and Slater ('61) in which they find that lactic dehydrogenase is located apically in certain epithelial cells of the body of the epididymis of the mouse, an anatomically convenient location for secretion of lactate or pyruvate into the epididymal lumen. They also find the activity of this enzyme to be under the partial control of androgens, showing a significantly lowered activity following orchidectomy or vasa efferentiectomy and a response to testosterone replacement in the orchidectomized animals.

It is suggested then, that the epididymal metabolism is oriented to the maintenance and development of epididymal spermatozoa during the maturation period in the epididymal tubules by the secretion of glycolytic end products (lactate) into the lumen, and the utilization of the metabolites by the spermatozoa for the support of oxidative processes and to furnish through pyruvate the intermediate for amino acid transamination, protein biosynthesis, and fatty acid synthesis.

\section{ACKNOWLEDGMENTS}

The author gratefully acknoweldges the help of Drs. S. Roseman, D. G. Shappirio, K. F. Guthe, and particularly Dr. J. M. Allen during the progress of the research presented here, and in the writing of the manuscript. 


\section{LITERATURE CITED}

Allen, J. M., and J. J. Slater 1961 A cytochemical analysis of the lactic dehydrogenase and diphosphopyridine nucleotide-diaphorase system in the epididymis of the mouse. J. Histochem. Cytochem., 9: 221-233.

Annison, E. F., T. W. Scott and G. M. H. Waites 1963 The role of glucose and acetate in the oxidative metabolism of the testis and epididymis of the ram. Biochem. J., 88 (3): 482-488.

Barker, S. B. 1957 Preparation and colorimetric determination of lactic acid. pp. 241-246. In: Colowick, S. P. and N. O. Kaplan (Ed.). Methods in Enzymology, Vol. III. Academic Press Inc., New York, New York.

Braus, H., and E. Redenz 1924 Nebenhoden and samenfaden. Verhandel. Anst. Ges. (Suppl.) Anat. Anz., 58: 121-131.

Chance, B., and B. Hess 1959 Spectroscopic evidence of metabolic control. Rapid measurements of intracellular events afford new evidence on mechanisms for metabolic control. Science, 129: 700-708.

Dryer, R. L., A. R. Tammes and J. I. Routh 1957 The determination of phosphorous and phosphatase with N-phenyl-p-phenylenediamine. J. Biol. Chem., 225: 177-183.

Elliott, P. R. 1965 The effect of efferentiectomy and orchidectomy on the metabolism of the epididymis of the mouse. J. Cell. and Comp. Physiol., 66: 293-302.

Flipse, R. J. 1962 Comments on certain aspects of the metabolism of spermatozoa, pp. 133-136. In: Spermatozoan Motility (D. W. Bishop, Ed.). A.A.A.S. Publ. no. 72, Washington, D. C.

Hartree, E. F., and T. Mann 1958 Plasmalogen in ram semen and its role in sperm metabolism. Biochem., J., 69: Proc. Biochem. Soc., 50 pp. 1959 Plasmalogen in ram semen and its role in sperm metabolism. Biochem. J., 71; 423-433.

1960 Crystalline lysoplasmalogen (lypophosphatidal choline): preparation from heart muscle and action on erythrocytes and spermatozoa. Biochem. J., 72: 251-258.

Henle, G., and C. A. Zittle 1942 Studies of the metabolism of bovine epididymal spermatozoa. Am. J. Physiol., 136: 70-78.

Krebs, H. A. 1950 Body size and tissue respiration. Biochem. Biophys. Acta, 4: 249-269.

Lardy, H. A., R. G. Hansen and P. H. Phillips 1945 The metabolism of bovine epididymal sperm. Arch. Biochem., 6: 41-51.

LePage, G. A. 1948 Glycolysis in tumor homogenates. J. Biol. Chem., 176: 1009-1020.
1950 A comparison of tumor and normal tissues with respect to factors effecting the rate of anaerobic glycolysis. Cancer Res., 10: 77-88.

Levy, M. 1936 Studies on enzymatic histochemistry, XVII. A micro Kjeldahl estimation. Compt. Rend. Trav. Carlsberg, Ser. Chimo., 21: 101-110.

Lynen, F., G. Hartmann, K. F. Netter and A. Schuegraf 1959 Phosphate turnover and Pasteur effect, pp. 256-273. In: Ciba Foundation Symposium on the Regulation of Cell Metabolism. Wolstenholme, G. E. W., and C. M. O'Connor (Ed.). Little, Brown and Co., Boston, Mass.

Maneely, R. B. 1959 Epididymal structure and function, a critical review. Acta Zool., 40: 1-21.

Mann, T, 1954 The Biochemistry of Semen. John Wiley and Sons, Inc., New York, 240 pp.

Mann, T., and T. Glover 1954 Contribution of the seminal vesicles to the composition of whole semen. J. Endocrin., 10: IV.

Racker, E., and R. Wu 1959 Limiting factors in glycolysis of ascites tumor cells and the Pasteur effect. pp. 205-218. In: Ciba Foundation Symposium on the Regulation of Cell Metabolism. Wolstenholme, G. E. W., and C. M. O'Connor (Ed.). Little, Brown and Co., Boston, Mass.

Salisbury, G. W., and J. R. Lodge 1962 Metabolism of spermatozoa. Adv, in Enzymol., 24: 35-104.

Spector, W. S. (Ed.) 1956 Handbook of Biological Data, p. 260. W. B. Saunders Co., Philadelphia, Pa.

Stoesz, P. A., and G. A. LePage 1949 Glycolysis in liver homogenates. J. Biol. Chem., 180: 587-595.

Terner, C. 1962 Oxidative and biosynthetic reactions in spermatozoa, pp. 88-98. In: Spermatozoan Motility (D. W. Bishop, Ed.). A.A.A.S. Publ. no. 72, Washington, D. C.

Umbreit, W. W., R. H. Burris and J. F. Stauffer 1957 Manometric Techniques. Burgess Publ. Co., Minneapolis, Minnesota, $338 \mathrm{pp}$.

Young, W. C. 1929a A study of the function of the epididymis. I. Is the attainment of full spermatozoan maturity attributable to some specific action of the epididymal secretion? $J$. Morph., 47: 479-495.

1929b A study of the function of the epididymis. II. The importance of the aging process in spermatozoa. J. Morph., 48: 475-491. 